\title{
The sensitivity and specificity of radiological features of Hirschsprung's disease in a cohort of South African children
}

\begin{tabular}{|c|c|}
\hline \multicolumn{2}{|c|}{$\begin{array}{l}\text { Authors: } \\
\text { Sucari S.C. Vlok }{ }^{1} \\
\text { Sam W. Moore }^{2} \\
\text { Pawel T. Schubert } \\
\text { Richard D. Pitcher } \\
\text { Rid }\end{array}$} \\
\hline \multicolumn{2}{|c|}{$\begin{array}{l}\text { Affiliations: } \\
{ }^{1} \text { Department of } \\
\text { Radiodiagnosis, Tygerberg } \\
\text { Hospital, University of } \\
\text { Stellenbosch, South Africa }\end{array}$} \\
\hline \multicolumn{2}{|c|}{$\begin{array}{l}\text { 2Department of Paediatric } \\
\text { Surgery, Tygerberg Hospital, } \\
\text { University of Stellenbosch } \\
\text { South Africa }\end{array}$} \\
\hline \multicolumn{2}{|c|}{$\begin{array}{l}{ }^{3} \text { Department Anatomical } \\
\text { Pathology, University of } \\
\text { Stellenbosch, Tygerberg } \\
\text { Hospital South Africa }\end{array}$} \\
\hline \multicolumn{2}{|c|}{$\begin{array}{l}\text { Corresponding author: } \\
\text { Sucari Vlok, } \\
\text { sucarivlok@gmail.com }\end{array}$} \\
\hline \multicolumn{2}{|c|}{$\begin{array}{l}\text { How to cite this article: } \\
\text { Vlok SSC, Moore SW, } \\
\text { Schubert PT, Pitcher RD. } \\
\text { The sensitivity and specificity } \\
\text { of radiological features of } \\
\text { Hirschsprung's disease in } \\
\text { a cohort of South African } \\
\text { children. S Afr J Rad. } \\
\text { 2017;21(1), a1165. https:// } \\
\text { doi.org/10.4102/sajr. } \\
\text { v21i1.1165 }\end{array}$} \\
\hline \multicolumn{2}{|c|}{$\begin{array}{l}\text { Copyright: } \\
\text { (c) 2017. The Authors. } \\
\text { Licensee: AOSIS. This } \\
\text { is licensed under the } \\
\text { Creative Commons } \\
\text { Attribution License. }\end{array}$} \\
\hline \multicolumn{2}{|c|}{ Read online: } \\
\hline 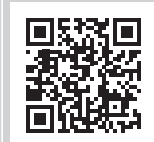 & $\begin{array}{l}\text { Scan this QR } \\
\text { code with your } \\
\text { smart phone or } \\
\text { mobile device } \\
\text { to read online. }\end{array}$ \\
\hline
\end{tabular}

Background: Hirschsprung's disease (HD) is classically defined as the absence of ganglion cells of the myenteric plexus of the bowel. Patients typically present with delayed passage of meconium and specific features on plain radiograph and contrasted enema supporting the diagnosis. Rectal biopsy remains the gold standard.

Hypothesis: The radiological features of HD in South African children are distinct from those described in other parts of the world and may be influenced by a number of factors, including delayed diagnosis in a resource-limited setting, higher proportion of cases with total colonic aganglionosis and higher prevalence of allied disorders.

Aims and objectives: To assess the diagnostic accuracy of the radiological features of HD in a cohort of South African (SA) children and to compare and contrast these findings with published international works in order to facilitate the early diagnosis of HD disease in our setting.

Methods: A retrospective audit of the radiological features on abdominal radiograph and contrasted enema of all the patients who received suction rectal biopsies after presenting with clinical features of HD at Tygerberg Children's Hospital, Cape Town, South Africa, from January 2007 through March 2015 was performed, with prospective component leading up to May 2016.

Conclusion: Pathology results have been revealed, and the sensitivity and specificity of the radiological findings was calculated, compared with those in the literature and presented at the SASPI Paediatric Imaging Congress in November 2016.

Note: A selection of conference abstracts: RSSA/SASPI Paediatric Imaging Congress, 03-06 November 2016, Spier Estate, Stellenbosch, South Africa. Faculty collaborators: Professor Kassa Darge (Body Imaging University of Pennsylvania, Philadelphia, USA), Professor South Africa. Faculty collaborators: Professor Kassa Darge (Body Imaging, University of Pennsylvania, Philadelphia, USA), Professor
Edward Lee (Thoracic Imaging, Harvard University, USA), Professor Beverley Newman (Cardiac Imaging, Stanford University, California, Udward Lee (Thoracic Imaging, Harvard University, USA), Professor Beverley Newman (Cardiac Imaging, Stanford University, California, USA), Professor Kimberly Applegate (Image Gently and Body Imaging, Emory University, Atlanta, USA) and Professor Savvas Andronikou
(Thoracic Imaging, University of Bristol, UK) supported by South African Paediatric Radiologists, co-ordinated by Dr Jaishree Naidoo, President of the African Society of Paediatric Imaging and Head of Division of Paediatric Radiology, Charlotte Maxeke Johannesburg Academic Hospital. 